\title{
KAJIAN EKSPERIMENTAL PENGARUH PENGGANTIAN SEBAGIAN SEMEN DENGAN LIMBAH LAS KARBIT PADA MORTAR
}

\author{
Dita Aninda ${ }^{1, *)}$, Putri Achir W. ${ }^{1)}$, Muhammad Fajar A. ${ }^{1)}$, Dianita Ratna K. ${ }^{1)}$, \\ Triwardaya $^{1)}$ \\ ${ }^{1)}$ Jurusan Teknik Sipil Politeknik Negeri Semarang \\ Jl. Prof. Soedarto SH, Tembalang Semarang 50275 Telepon (024) 76480569 \\ ${ }^{*}$ Email: ditaaninda@gmail.com
}

\begin{abstract}
The Development of residential facilities will affect the increase in needs of building materials.. Cement is one of the building materials whose raw materials come from nature. Availability of natural resources will affect the production of cement. Carbide welding waste is the remainder of the carbide reaction to water which produces acyetilene gas where $60 \%$ of the waste contains Calcium Oxide (CaO) which is the main constituent of cement. This study aims to analyze the effect of partial replacement of cement with carbide weld waste on mortar compressive strength. The study was conducted by making a mortar cube with dimensions of 5 $\mathrm{cm} \times 5 \mathrm{~cm} \times 5 \mathrm{~cm}$ with mixed proportions of 1PC: $3 P S$. Variation of partial replacement of cement with carbide welding waste used as much as 0\%, 5\%, 10\%, $15 \%$, and $20 \%$. The results showed that the mortar compressive strength without carbide welding waste was used as the control variable, amounting to 329.33 $\mathrm{kg} / \mathrm{cm} 2$. Mortar compressive strength with the proportion of partial replacement of cement with carbide welding waste 5\%, 10\%, 15\%, and 20\% respectively are 286.38 $\mathrm{kg} / \mathrm{cm} 2,243.42 \mathrm{~kg} / \mathrm{cm} 2,200.47 \mathrm{~kg} / \mathrm{cm} 2$, and $157.51 \mathrm{~kg} / \mathrm{cm} 2$. based on pengijuan results indicate that the mortar is included in type $M$ at a proportion of a maximum of $15 \%$ with a compressive strength of $200.47 \mathrm{~kg} / \mathrm{cm} 2$ according to the minimum requirements of $175 \mathrm{~kg} / \mathrm{cm} 2$.
\end{abstract}

Kata kunci : experimental, compressive strength, waste of carbide weld, mortar

\section{PENDAHULUAN}

Berdasarkan data Asosiasi Semen Indonesia (ASI), di Januari-November 2017 ini total penjualan emiten (saham) berkode SMGR (PT Semen Indonesia (Persero) Tbk, sebelumnya bernama PT Semen Gresik (Persero) Tbk ini adalah 26,43 juta ton, alias tumbuh $9,9 \%$ dibandingkan periode yang sama tahun lalu 24,05 juta ton. Sedangkan penjualan domestiknya tumbuh $5,2 \%$ menjadi 24,73 juta ton dari Januari-November tahun lalu,
23,49 juta ton. Kenaikan paling tajam berasal dari pasar ekspor yang meningkat hingga tiga kali lipat sampai November 2017 ini. Sampai November 2016, ekspor SMGR hanya 550.000 ton, sedangkan periode yang sama tahun ini sudah mencapai 1,7 juta ton (Rahmawati, 2017).

Dengan semakin banyaknya jumlah kebutuhan akan pemakaian semen maka akan semakin banyak pula pembangunan yang akan dicapai. Dalam laju pertumbuhan penduduk 
yang semakin tinggi berakibat pada peningkatan kebutuhan akan sarana hunian. Pengembangan saranan hunian akan berpengaruh terhadap peningkatan kebutuhan bahan bangunan terutama semen. Dalam pembuatan semen dibutuhkan energi yang sangat besar dan bahan baku yang diambil untuk pembuatan semen portland merupakan bahan yang berasal dari alam sehingga berpengaruh terhadap ketersediaan sumber daya alam yang semakin lama akan semakin menipis. Salah satu cara untuk mengatasi permintaan kebutuhan bahan bangunan tersebut adalah dengan cara meningkatkan pemberdayaan sumber daya lokal yang berada di lingkungan kita (Aswad \& Ferdyan, 2013).

Pemberdayaan sumber daya lokal dapat berupa pemanfaatan limbah. Pemanfaatan limbah disamping dapat mengurangi pencemaran lingkungan juga dapat digunakan sebagai alternatif pengganti bahan bangunan yang sudah ada. Salah satu limbah yang dapat dimanfaatkan dengan baik adalah limbah industri bengkel las karbit. Diperkirakan dalam sehari bengkel las akan menghasilkan limbah karbit sebanyak $2 \mathrm{~kg}$, maka dalam hitungan tahun cukup banyak jumlah limbah karbit yang dihasilkan terbuang percuma dan belum dimanfaatkan secara optimal. Limbah las karbit yang cukup melimpah dengan banyaknya pengusaha las karbit yang membuang limbah sisa las tanpa mengolahnya. Limbah las karbit adalah pembuangan sisa-sisa dari proses penyambungan logam yang menggunakan gas karbit sebagai bahan bakar (Saputra, 2017).

Penambahan limbah karbit merupakan upaya untuk memanfaatkan limbah sebagai bahan perekat, karena komposisi kimia limbah karbit $60 \%$ mengandung Calsium Oksida $(\mathrm{CaO})$, $\mathrm{SiO}_{2}=1.48 \%, \mathrm{Fe}_{2} \mathrm{O}_{3}=0,09 \%, \mathrm{Al}_{2} \mathrm{O}_{3}=$ 9,07\% dll, diketahui bahwa unsur pembentuk utama dari semen adalah Calsium yang berasal dari batu kapur, dengan begitu maka limbah karbit hasil pengelasan merupakan material pembentuk semen (Rajiman, 2015).

Produksi semen juga menghasilkan efek yang tidak ramah terhadap lingkungan. Cerobong cerobong pabrik semen akan menyemburkan asap dan debu yang menjadi pencemaran udara. Berbagai penyakit yang berhubungan dengan pernapasan timbul sebagai konsekuensi debu adanya pabrik semen. Berdasarkan dari proses pembuatan semen portland, produksi satu ton semen portland menghasilkan sekitar satu ton gas karbon dioksida yang dilepaskan ke atmosfer (Hardjito dkk. 2008). Sumbangan industri semen terhadap total emisi karbon dioksida sangat besar, sehingga perlu dilakukan penelitian sebagai upaya untuk meminimalkan emisi tersebut. Penggantian sejumlah bagian semen maupun total pada mortar yang lebih ramah lingkungan merupakan solusi yang dapat mengurangi dampak negatif terhadap lingkungan.

Kusdiyono dan Rochadi (2012) melakukan pengujian campuran mortar dengan bahan tambah limbah batu bara (fly ash). Persamaan dalam 
penelitian ini yaitu mengkaji mengenai kuat tekan mortar melalui benda uji kubus ukuran $5 \mathrm{~cm}$ x $5 \mathrm{~cm} \mathrm{x}$ $5 \mathrm{~cm}$ pada berbagai umur $(7,14$, dan 28) hari. Rajiman (2015) melakukan pengujian beton kubus dengan subtitusi feldspart dan limbah karbit dalam beton dengan variasi campuran limbah karbit sebesar 10\%, 20\%, 30\%, $40 \%$, dan $50 \%$. Hasil penelitian menunjukkan nilai kuat tekan meningkat seiring dengan penambahan limbah karbit sebesar $40 \%$ dengan nilai kuat tekan sebesar 436,20 kg/ $\mathrm{cm}^{2}$. Hartono, dkk (2009) melakukan penelitian dengan mencampurkan abu sampah organik yang mengandung unsur silika dengan limbah karbit yang telah dikeringkan sebagai bahan pengganti semen mortar. Hasil penelitian menunjukkan bahwa konsistensi normal semua variasi campuran lebih tinggi daripada semen dan waktu pengikatan memerlukan waktu yang lebih singkat daripada semen. Kuat tekan mortar tertinggi diperoleh dari campuran $70 \%$ abu sampah organik dan $30 \%$ limbah karbit, yaitu sebesar $26,4 \mathrm{~kg} / \mathrm{cm}^{2}$ pada umur 14 hari.

Ali, dkk (2014) melakukan penelitian dengan mencampurkan bottom ash sebagai pengganti pasir dengan limbah karbit sebagai bahan tambah semen pada batako dengan perbandingan 1:8 untuk PC dan pasir, variasi perbandingan $\mathrm{PC}$ dengan bottom ash sama dengan variasi perbandingan PC dan pasir dengan bahan tambah semen limbah karbit sebanyak 0\%, 10\%, 20\%, dan $30 \%$. Berdasarkan hasil pengujian, kuat tekan batako paling tinggi pada variasi $30 \%$ limbah karbit dengan pasir sebagai agregat halus yaitu 6,91 $\mathrm{MPa}$, sedangkan kuat tekan dengan bottom ash sebagai pengganti agregat halus dengan variasi limbah karbit yang sama didapatkan nilai kuat tekan sebesar 5,23 MPa. Wallah dan Pandaleke (2014) melakukan pengujian menggunakan abu terbang (fly ash) sebagai bahan substitusi parsial semen pada mortar. Hasil penelitian menunjukkan bahwa nilai kuat tekan optimum proporsi 1Pc:3Ps, 1Pc:4Ps dan 1Pc:5Ps berturut-turut sebesar 27,71 $\mathrm{MPa}, 21,98 \mathrm{MPa}$ dan 14,91 $\mathrm{MPa}$, didapat dari campuran dengan substitusi parsial semen menggunakan abu terbang (fly ash) sebanyak 15\%, 5\%, dan 15\%. Pada proporsi 1Pc:8Ps didapat kuat tekan optimum dari campuran dengan substitusi parsial semen dengan abu terbang (fly ash) sebanyak 15\%. Kuat tekan mortar yang menggunakan abu terbang (fly ash) sebagai substitusi parsial semen diperoleh f'c optimum = 6,18 MPa dibandingkan dengan yang tidak menggunakan abu terbang (fly ash) f'c minimum $=4,6 \mathrm{MPa}$. Kuat tekan kondisi optimum mengalami kenaikan sebesar $25,57 \%$ dari kuat tekan tanpa menggunakan abu terbang (fly ash) sebagai substitusi parsial semen.

Latif, dkk (2015) melakukan penelitian sifat fisik, waktu ikat, kepadatan dan kuat tekan kalsium karbit sebagai alternatif semen pada mortar. Enam campuran mortar yang mengandung pengganti kalsium karbid yang berbeda hingga $40 \%$ dari berat 
dan satu kontrol hasil mortar pengujian kuat tekan mortar sesuai SK dilaporkan. Hasil penelitian SNI M-111-1990-03 pada umur 7, 14, menunjukkan bahwa ada peningkatan dan 28 hari.

sistematis dalam pengaturan waktu awal dan akhir dengan penurunan kepadatan dan kekuatan mortar. Rattanashotinunt, dkk (2013) melakukan pengujian residu kalsium karbit dan abu ampas tebu sebagai bahan semen untuk pengganti semen Portland dalam beton. Hasil yang didapat adalah mungkin untuk menggunakan campuran residu kalsium karbit dan abu ampas tebu sebagai bahan semen untuk pengganti semen Portland dalam beton. Hasil penelitian menunjukan bahwa beton yang dibuat dengan residu kalsium karbit dan abu ampas tebu mengandung $90 \mathrm{~kg} / \mathrm{m}^{3}$ semen Portland untuk mencapai kuat tekan yang sama.

Sumbangan industri semen terhadap total emisi karbon dioksida sangat besar, sehingga perlu dilakukan penelitian sebagai upaya untuk meminimalkan emisi tersebut. Penggantian sejumlah bagian semen maupun total pada mortar yang lebih ramah lingkungan merupakan solusi yang dapat mengurangi dampak negatif terhadap lingkungan. Berdasarkan penelitian yang telah dilakukan tersebut perlu dilakukan penelitian lebih lanjut. Salah satu penelitian yang dilakukan dengan cara penggantian sebagaian semen dengan limbah las karbit dengan proporsi penggantian sebesar $0 \%, 5 \%, 10 \%$, $15 \%$, dan $20 \%$ dimana dilakukan

\section{METODE PENELITIAN \\ Lokasi dan Waktu Penelitian}

Lokasi penelitian ini dilakukan di Laboratorium Bahan Politeknik Negeri Semarang dan waktu pelaksanaan penelitian dilakukan selama bulan April - Juni 2018.

\section{Pelaksanaan Penelitian}

Pada penelitian ini sebelum membuat benda uji mortar, peneliti terlebih dahulu melakukan uji karakteristik agregat halus dan kandungan kimia limbah las karbit (SEM EDX) yang akan digunakan sebagai pengganti sebagian semen pada mortar. Limbah las karbit yang digunakan dikeringkan terlebih dahulu kemudian dihaluskan dan dilanjutkan dengan proses pengayakan. Pembuatan mortar menggunakan metode eksperimen dengan variasi limbah las karbit sebagai pengganti sebagian semen yaitu $0 \%, 5 \%, 10 \%, 15 \%$, dan $20 \%$ dari berat semen, pembuatan mortar memperhatikan konsistensi yang diuji dengan flow table dengan mengukur pada empat bagian sehingga diperoleh nilai antara $110 \%-120 \%$. Benda uji mortar diuji kuat tekan pada umur 7 , 14, dan 28 hari dengan jumlah benda uji sebanyak 5 buah setiap campuran, sehingga total benda uji yang dibuat adalah 75 buah, jumlah benda uji disajikan pada Tabel 1. 
Tabel 1. Hubungan Variasi Campuran, Umur Uji, dan Jumlah Sampel

\begin{tabular}{|c|c|c|c|c|c|}
\hline \multirow{2}{*}{ No } & \multirow{2}{*}{$\begin{array}{l}\text { Penggantian Limbah Las } \\
\text { Karbit (dari berat semen) }\end{array}$} & \multicolumn{3}{|c|}{ Umur Uji (hari) } & \multirow{2}{*}{$\begin{array}{c}\text { Jumlah } \\
\text { Benda Uji }\end{array}$} \\
\hline & & 7 & 14 & 28 & \\
\hline 1 & $0 \%$ & 5 & 5 & 5 & 15 \\
\hline 2 & $5 \%$ & 5 & 5 & 5 & 15 \\
\hline 3 & $10 \%$ & 5 & 5 & 5 & 15 \\
\hline 4 & $15 \%$ & 5 & 5 & 5 & 15 \\
\hline 5 & $20 \%$ & 5 & 5 & 5 & 15 \\
\hline
\end{tabular}

Setelah mendapatkan data dari hasil kuat tekan, langkah selanjutnya adalah melakukan perhitungan kuat tekan. Perhitungan nilai kuat tekan dari benda uji dapat dilakukan dengan persamaan berikut :

Kuat Tekan beton $(\sigma b k)=\mathrm{P} / \mathrm{A}$

dimana :

$\mathrm{P}=$ beban maksimum dalam $\mathrm{N}$ atau

kgf;

$\mathrm{A}=$ luas bidang tekan kubus uji dalam $\mathrm{mm}^{2}$ atau $\mathrm{cm}^{2}$.

Setelah diketahui kuat tekan benda uji mortar, kemudian ditentukan kuat tekan rata-ratanya dan dibuat grafik hubungan antara kuat tekan mortar dengan prosentase limbah las karbit dan grafik hubungan antara kuat tekan mortar rata-rata dengan prosentase mortar. Untuk mengetahui pengaruh penggantian semen dengan limbah las karbit terhadap kuat tekan mortar maka harus mencari nilai koefisien korelasi (r).

a. Batas nilai $\mathrm{R}$

Nilai $\mathrm{R}$ terbesar ialah +1 , dan terkecil ialah -1 sehingga dapat ditulis $-1 \leq \mathrm{r} \leq+1$. Untuk $\mathrm{R}=+1$ disebut hubungan positif sempurna dan hubungannya linier langsung sangat tinggi. Sebaliknya jika $\mathrm{R}=-1$ disebut hubungan negating sempurna dan hubungannya tidak langsung (indirect) sangat tinggi, yang disebut inverse.

b. Tidak berlaku untuk sampel dengan varian $=0$, karena $\mathrm{z}$ tidak dapat dihitung dan akhirnya $\mathrm{R}$ tidak dapat dihitung juga.

c. R tidak mempunyai satuan (dimensi)

Jika $\mathrm{R}=+1$ diberi makna hubungan kedua variable adalah linier, positif dan sangat tinggi; dan jika $\mathrm{R}=-1$, diberi arti hubungan kedua variable adalah linier, negative dan sangat tinggi. Jika nilai $\mathrm{R}$ terdapat diantara -1 dan +1 , misalnya $+0,7 ;+0,01$; 0,5; -0,2 maka $\mathrm{R}$ yang kita hitung menurut Tabel 2.

Macam nilai $\mathrm{R}$

Setelah kita menghitung nilai $\mathrm{R}$ dari sekian banyak penelitian, akhirnya dapat disimpulkan bahwa nilai $\mathrm{R}$ itu dapat dibedakan atas lima macam yaitu: $+1,+0, \ldots, 0,-0, \ldots,-1$.

Atau dengan kata lain, harga maksimal $\mathrm{R}$ adalah +1 dan harga minimal $\mathrm{R}$ adalah -1 , yang apabila ditulis dalam bentuk matematis menjadi $-1 \leq \mathrm{r} \leq+1$. 
Tabel 2. Pedoman Interprestasi Koefisien Korelasi

\begin{tabular}{cc}
\hline $\mathrm{R}$ & Interprestasi \\
\hline 0 & Tidak Berkorelasi \\
$0,01-0,20$ & Sangat Rendah \\
$0,21-0,40$ & Rendah \\
$0,41-0,60$ & Agak Rendah \\
$0,61-0,80$ & Cukup \\
$0,81-0,99$ & Tinggi \\
1 & Sangat Tinggi \\
\hline
\end{tabular}

(Sumber : Usman Husaini dan Akbar Setiady P., 2008)

\section{HASIL DAN PEMBAHASAN}

Hasil Pengujian Agregat Halus

Sebelum digunakan untuk pembuatan mortar dengan penggantian sebagian semen menggunakan limbah las karbit dilakukan pengujian terhadap agregat halus. Pengujian terhadap agregat halus dilakukan untuk mengetahui karakteristik dan kualitas dari pasir yang akan digunakan, pengujian yang dilakukan meliputi pengujian kadar organik, kadar butir halus lolos saringan No.200, analisa ayak, kadar air, dan berat jenis agregat halus. Pengujian dilaksanakan di Laboratorium Bahan Jurusan Teknik Sipil Politeknik Negeri Semarang.

Tabel 3. Tabel Hasil Analisa Pengujian Agregat Halus

\begin{tabular}{|c|c|c|c|c|}
\hline No & Jenis Pengujian & Spesifikasi & Hasil & Keterangan \\
\hline 1. & $\begin{array}{l}\text { Pengujian Kadar } \\
\text { Organik }\end{array}$ & Lebih Muda & Lebih Muda & Memenuhi syarat \\
\hline 2. & $\begin{array}{l}\text { Kadar Butir Halus } \\
\text { Lewat Saringan No. } \\
200\end{array}$ & $\operatorname{Max}=5 \%$ & $\begin{array}{l}\text { Lolos Saringan } \\
\text { No. } 200=3,99 \%\end{array}$ & Memenuhi syarat \\
\hline 3. & $\begin{array}{l}\text { Pengujian Analisa } \\
\text { Ayak Agregat Halus }\end{array}$ & $\mathrm{FM}=1,5-3,8$ & $\begin{array}{l}\text { Zona } 2 \\
\mathrm{FM}=2,55\end{array}$ & Memenuhi syarat \\
\hline 4. & $\begin{array}{l}\text { Pengujian Kadar Air } \\
\text { Agregat Halus }\end{array}$ & - & $7,85 \%$ & Memenuhi syarat \\
\hline 5 & $\begin{array}{l}\text { Pengujian Berat } \\
\text { Jenis Agregat Halus }\end{array}$ & $\begin{array}{l}\mathrm{BJ} \min =2,55 \\
\text { Penyerapan air } \\
\max =3 \%\end{array}$ & $\begin{array}{l}\mathrm{BJ}=2,58 \\
\text { Penyerapan Air }= \\
2,74 \%\end{array}$ & Memenuhi syarat \\
\hline
\end{tabular}

Berdasarkan Tabel 3 diperoleh hasil pengujian agregat halus sebagai berikut.

1. Agregat halus tidak mengandung zat organik, karena berdasarkan hasil uji, warna cairan lebih muda dibanding dengan warna zat pembanding.

2. Hasil dari pengujian kadar butir halus lewat saringan no. 200 diketahui butiran halus yang lolos sebesar 3,99\%. Menurut 
SNI 03-4142-1996 bahwa jumlah kadar lumpur atau partikel yang sangat halus tidak boleh melebihi 5\%. Sehingga agregat halus dinyatakan memenuhi persyaratan.

3. Hasil percobaan dan analisa ayak agregat halus didapatkan hasil FM (Fineness Modulus) agregat halus 2,55 (sesuai dengan syarat 1,5-3,8). Agregat halus masuk dalam zona 2 dan merupakan agregat halus yang berbutir halus agak kasar.

4. Berdasarkan pengujian kadar air pada agregat halus didapatkan hasil sebesar 7,85\%. Nilai kadar air $7,85 \% \geq$ penyerapan air $2,74 \%$, sehingga agregat halus dinyatakan dalam keadaan basah.
5. Agregat halus yang digunakan sebagai benda uji merupakan Pasir Muntilan dengan berat jenis sebesar 2,58 berdasarkan hasil pengujian. Nilai tersebut menunjukkan bahwa agregat halus memenuhi persyaratan berat jenis minimal 2,55.

\section{Analisis Limbah Las Karbit}

Limbah las karbit yang digunakan juga perlu untuk diuji kandungan kimia yang terdapat didalamnya. Pengujian kandungan kimia pada limbah las karbit dilakukan di Laboratorium Terpadu Universitas Diponegoro Semarang dengan menggunakan metode SEM EDX perbesaran 5000 Kali (Gambar 1)

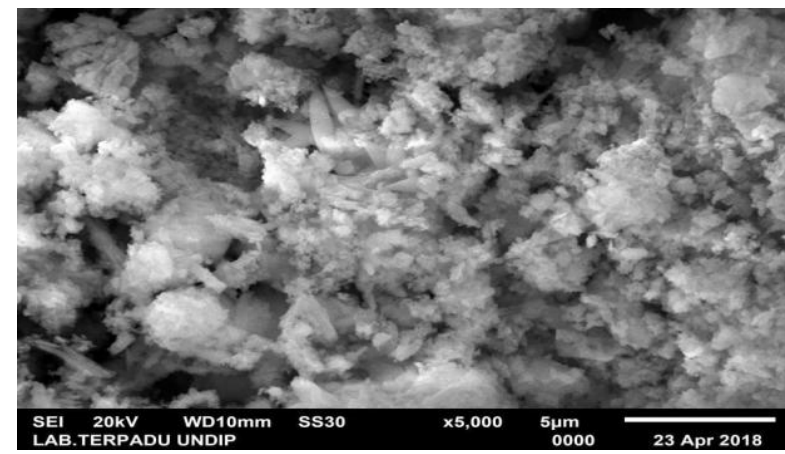

Gambar 1. Perbesaran Limbah Las Karbit 5000 x

Tabel 4. Hasil Pengujian Limbah Las Karbit (SEM EDX)

\begin{tabular}{clc}
\hline No & \multicolumn{1}{c}{ Komponen } & Komposisi $(\%$ berat $)$ \\
\hline 1. & Karbon, $\mathrm{C}$ & 23,75 \\
2. & Alumina, $\mathrm{Al}_{2} \mathrm{O}_{3}$ & 1,83 \\
3. & Silika Dioksida, $\mathrm{SiO}_{2}$ & 1,76 \\
4. & Sulfit, $\mathrm{SO}_{3}$ & 1,57 \\
5. & Kalsium Oksida, $\mathrm{CaO}$ & 67,25 \\
6. & Tembaga (II) Oksida, $\mathrm{CuO}$ & 1,67 \\
7. & Zirkonium Dioksida, $\mathrm{ZrO}_{2}$ & 2,13 \\
\hline
\end{tabular}


Berdasarkan dari hasil pengujian limbah las karbit dengan metode SEM EDX yang ditunjukkan pada Tabel 4 didapatkan komposisi kimia limbah las karbit $67.25 \%$ mengandung kalsium $(\mathrm{CaO}), \mathrm{SiO}_{2}=$ $1.76 \%, \mathrm{Al}_{2} \mathrm{O}_{3}=1.83 \%$. Diketahui bahwa unsur pembentuk utama dari semen adalah kalsium yang berasal dari batu kapur, dengan begitu maka limbah las karbit hasil dari pengelasan merupakan material pembentuk semen karena bahan baku semen portland yang baik mengandung 60\% - 67\% kalsium. Selain itu bahan pembentuk semen terdiri dari silika dan alumina. Dari hasil yang ditunjukkan Tabel 4.2 limbah las karbit yang diuji memiliki kandungan silika dan alumina yang cukup, sehingga dapat digunakan dalam pembuatan mortar sebagai penggantian sebagian semen.

\section{Hasil Pengujian Konsistensi Mortar} Setelah melakukan pengujian material bahan agregat halus, dalam pembuatan benda uji sebelum memasukkan benda uji kedalam cetakan perlu dilakukan pengujian konsistensi mortar untuk mengetahui sifat kelecakan mortar yang baik dan sesuai dengan derajat kecairan (flow) berkisar $110-120 \%$. Pengujian konsistensi mortar dilakukan setiap proporsi pada benda uji.

Berdasarkan dari hasil data pengujian pada Tabel 5, pada pengujian pertama menunjukkan derajat kecairan (flow) sebesar 99\% dan jumlah air $250 \mathrm{ml}$. Mortar konsistensi standar mempunyai derajat kecairan (flow) antara 110 -
120\% sehingga pada percobaan pertama belum memenuhi standar konsistensi. Dilakukan penambahan air sebanyak $50 \mathrm{ml}$ pada percobaan kedua dan menunjukkan hasil derajat kecairan (flow) sebesar 114,5\% sehingga memenuhi standar derajat kecairan (flow) dengan jumlah air sebanyak $300 \mathrm{ml}$.

Berdasarkan dari hasil data pengujian pada Tabel 6, pengujian konsistensi mortar dengan penggantian $5 \%$ dari berat semen dengan limbah las karbit menunjukkan derajat kecairan (flow) sebesar $113,5 \%$ dengan jumlah air sebanyak $300 \mathrm{ml}$ sehingga pengujian memenuhi standar derajat kecairan (flow).

Berdasarkan dari hasil data yang ditunjukkan pada Tabel 7 pengujian konsistensi mortar dengan penggantian $10 \%$ dari berat semen dengan limbah las karbit menunjukkan derajat kecairan (flow) sebesar $118,7 \%$ dengan jumlah air sebanyak $300 \mathrm{ml}$ sehingga pengujian memenuhi standar derajat kecairan (flow).

Berdasarkan dari hasil data pengujian pada Tabel 7, pengujian konsistensi mortar dengan penggantian $15 \%$ dari berat semen dengan limbah las karbit menunjukkan derajat kecairan (flow) sebesar 106,6\% dengan jumlah air sebanyak $300 \mathrm{ml}$, sehingga pada pengujian pertama belum memenuh konsistensi standar mortar. Pengujian kedua dilakukan penambahan air suling sebesar $10 \mathrm{ml}$ dari jumlah sebelumnya dan pada 
data hasil pengujian yang ditunjukkan pada Tabel 8 menunjukkan angka konsistensi sebesar $110 \%$ dengan jumlah air sebanyak $310 \mathrm{ml}$, sehingga pengujian kedua memenuhi standar derajat kecairan (flow).

Berdasarkan dari hasil data yang ditunjukkan pada Tabel 9, pengujian konsistensi mortar dengan penggantian $20 \%$ dari berat semen dengan limbah las karbit menunjukkan derajat kecairan (flow) sebesar $112,5 \%$ dengan jumlah air sebanyak $310 \mathrm{ml}$, sehingga pada pengujian pertama belum memenuhi konsistensi standar mortar.

Tabel 5. Konsistensi Mortar Tanpa Penggantian dengan Limbah Las Karbit

\begin{tabular}{cccccccc}
\hline No. & \multicolumn{4}{c}{ Diameter (D) } & \multirow{2}{*}{$\begin{array}{c}\text { Flow } \\
(\%)\end{array}$} & $\begin{array}{c}\text { Air } \\
(\mathrm{ml})\end{array}$ & Keterangan \\
\cline { 2 - 5 } Benda Uji & 1 & 2 & 3 & 4 & & \\
\hline 1 & 25 & 25,5 & 25 & 23,5 & 99 & 250 & \\
2 & 28,5 & 29 & 29 & 28 & 114,5 & 300 & FAS \\
\hline
\end{tabular}

Tabel 6. Konsistensi Mortar Penggantian Sebagian Semen (5\%)

\begin{tabular}{|c|c|c|c|c|c|c|c|}
\hline \multirow{2}{*}{$\begin{array}{c}\text { No. } \\
\text { Benda Uji }\end{array}$} & \multicolumn{4}{|c|}{ Diameter (D) } & Flow & Air & \multirow{2}{*}{ Keterangan } \\
\hline & 1 & 2 & 3 & 4 & $(\%)$ & $(\mathrm{ml})$ & \\
\hline 1 & 28 & 28,5 & 28,5 & 28,5 & 113,5 & 300 & FAS \\
\hline
\end{tabular}

Tabel 7. Konsistensi Mortar Penggantian Sebagian Semen (10\%)

\begin{tabular}{|c|c|c|c|c|c|c|c|}
\hline \multirow{2}{*}{$\begin{array}{c}\text { No. } \\
\text { Benda Uji }\end{array}$} & \multicolumn{4}{|c|}{ Diameter (D) } & \multirow{2}{*}{$\begin{array}{l}\text { Flow } \\
(\%)\end{array}$} & \multirow{2}{*}{$\begin{array}{l}\text { Air } \\
(\mathrm{ml})\end{array}$} & \multirow{2}{*}{ Keterangar } \\
\hline & 1 & 2 & 3 & 4 & & & \\
\hline 1 & 28 & 29 & 31 & 30,7 & 118,7 & 300 & FAS \\
\hline
\end{tabular}

Tabel 8. Konsistensi Mortar Penggantian Sebagian Semen (15\%)

\begin{tabular}{cccccccc}
\hline No. & \multicolumn{4}{c}{ Diameter (D) } & \multirow{2}{*}{$\begin{array}{c}\text { Flow } \\
(\%)\end{array}$} & $\begin{array}{c}\text { Air } \\
(\mathrm{ml})\end{array}$ & Keterangan \\
\cline { 2 - 5 } Benda Uji & 1 & 2 & 3 & 4 & & \\
\hline 1 & 26,9 & 26,4 & 26,3 & 27 & 106,6 & 300 & \\
2 & 28,5 & 27,5 & 27 & 27 & 110 & 310 & FAS \\
\hline
\end{tabular}

Tabel 9. Konsistensi Mortar Penggantian Sebagian Semen (20\%)

\begin{tabular}{cccccccc}
\hline No. & \multicolumn{4}{c}{ Diameter (D) } & Flow & Air & Keterangan \\
\cline { 2 - 5 } Benda Uji & 1 & 2 & 3 & 4 & $(\%)$ & $(\mathrm{ml})$ & FAS \\
\hline 1 & 28 & 28,5 & 28 & 28 & 112,5 & 310 & F \\
\hline
\end{tabular}

Hasil Pengujian Kuat Tekan Mortar Pengujian kuat tekan mortar dilakukan saat mortar telah berumur mencapai umur 7, 14, dan 28 hari. Pengujian kuat tekan dilakukan di
Laboratorium Bahan Jurusan Teknik Sipil Politeknik Negeri Semarang.

Pada Gambar 2 menunjukkan hasil pengujian mortar pada umur 7 hari, diketahui kuat tekan rata - rata terendah dicapai oleh mortar dengan 
proporsi penggantian sebagian semen dengan limbah las karbit sebesar 20\% yaitu $114.58 \mathrm{~kg} / \mathrm{cm}^{2}$. Mortar dengan proporsi normal menghasilkan kuat tekan rata - rata sebesar $256.61 \mathrm{~kg} / \mathrm{cm}^{2}$ dan kuat tekan rata - rata yang mendekati mortar normal yaitu mortar dengan proporsi $10 \%$ sebesar 204.75 $\mathrm{kg} / \mathrm{cm}^{2}$. Mortar dengan proporsi $5 \%$ dan $15 \%$ menghasilkan kuat tekan rata - rata sebesar $182.65 \mathrm{~kg} / \mathrm{cm}^{2}$ dan $142.37 \mathrm{~kg} / \mathrm{cm}^{2}$

Dari Gambar 3 didapatkan persamaan $\mathrm{y}=-6.4868 \mathrm{x}+245.06$. Persamaan tersebut dapat menunjukkan kuat tekan mortar normal pada umur 7 hari sebesar $245.06 \mathrm{~kg} / \mathrm{cm}^{2}$. Sedangkan, kuat tekan mortar pada penggantian sebagian semen dengan limbah las karbit sebesar $20 \%$ yaitu $115.32 \mathrm{~kg} / \mathrm{cm}^{2}$. Nilai koefisien $\mathrm{R}$ sebesar 0.93. Pada tabel pedoman interpretasi koefisien korelasi, nilai $\mathrm{R}$ tersebut memiliki tingkat hubungan yang tinggi. Jadi, dapat dinyatakan bahwa pada saat mortar berumur 7 hari, pengaruh penggantian sebagian semen dengan limbah las karbit dengan proporsi tertentu memiliki pengaruh yang kuat terhadap nilai kuat tekan. Namun, secara grafik dapat dilihat pada Gambar 3 semakin banyaknya prosen penggantian sebagian semen dengan limbah las karbit trend nya semakin menurun.

Pada Gambar 4 menunjukkan hasil pengujian mortar pada umur 14 hari, diketahui kuat tekan rata - rata maksimal dicapai oleh mortar normal yaitu $257.84 \mathrm{~kg} / \mathrm{cm}^{2}$. Mortar dengan proporsi $5 \%$ penggantian sebagian semen dengan limbah las karbit memiliki kuat tekan rata - rata mendekati kuat tekan mortar normal yaitu $223.84 \mathrm{~kg} / \mathrm{cm}^{2}$. Mortar dengan proporsi 10\%; 15\%; dan $20 \%$ menghasilkan kuat tekan rata - rata secara berturut - turut $208.39 \mathrm{~kg} / \mathrm{cm}^{2}$; $161.01 \mathrm{~kg} / \mathrm{cm}^{2}$; dan $151.36 \mathrm{~kg} / \mathrm{cm}^{2}$.

Dari Gambar 5 didapatkan persamaan $\mathrm{y}=-5.5158 \mathrm{x}+255.65$. Persamaan tersebut dapat menunjukkan kuat tekan mortar normal pada umur 14 hari sebesar $255.65 \mathrm{~kg} / \mathrm{cm}^{2}$. Sedangkan, kuat tekan mortar pada penggantian sebagian semen dengan limbah las karbit sebesar $10 \%$ yaitu $200.49 \mathrm{~kg} / \mathrm{cm}^{2}$. Pada proporsi $20 \%$ penggantian sebagian semen dengan limbah las karbit didapat nilai kuat tekan mortar yaitu $145.33 \mathrm{~kg} / \mathrm{cm}^{2}$. Nilai koefisien R sebesar 0.98. Pada tabel pedoman interpretasi koefisien korelasi, nilai $\mathrm{R}$ tersebut memiliki tingkat hubungan yang tinggi. Jadi, dapat dinyatakan bahwa pada saat mortar berumur 14 hari, pengaruh penggantian sebagian semen dengan limbah las karbit dengan proporsi tertentu memiliki pengaruh yang kuat terhadap nilai kuat tekan. Namun, secara grafik dapat dilihat pada Gambar 5 semakin banyaknya prosen penggantian sebagian semen dengan limbah las karbit trend nya juga semakin menurun.

Pada Gambar 6 menunjukkan hasil pengujian mortar pada umur 28 hari, diketahui kuat tekan rata - rata maksimal dicapai oleh mortar normal yaitu $340.56 \mathrm{~kg} / \mathrm{cm}^{2}$. Mortar dengan proporsi $5 \%$ penggantian sebagian 
semen dengan limbah las karbit menghasilkan kuat tekan rata - rata sebesar $283.42 \mathrm{~kg} / \mathrm{cm}^{2}$ dimana proporsi ini yang mendekati nilai kuat tekan rata - rata mortar normal. Kuat tekan rata - rata terendah dicapai oleh mortar dengan proporsi penggantian sebagian semen dengan limbah las karbit sebesar $15 \%$ yaitu 168.97 $\mathrm{kg} / \mathrm{cm}^{2}$. Mortar dengan proporsi $10 \%$ dan $20 \%$ menghasilkan kuat tekan rata - rata sebesar $241.15 \mathrm{~kg} / \mathrm{cm}^{2}$ dan $183.01 \mathrm{~kg} / \mathrm{cm}^{2}$.

Dari Gambar 7 didapatkan persamaan $\mathrm{y}=-8.5909 \mathrm{x}+329.33$. Persamaan tersebut dapat menunjukkan kuat tekan mortar normal pada umur 28 hari sebesar $329.33 \mathrm{~kg} / \mathrm{cm}^{2}$. Sedangkan, kuat tekan mortar pada penggantian sebagian semen dengan limbah las karbit sebesar 5\% dan $10 \%$ yaitu 286.38 $\mathrm{kg} / \mathrm{cm}^{2}$ dan $243.42 \mathrm{~kg} / \mathrm{cm}^{2}$. Nilai kuat tekan mortar proporsi $15 \%$ penggantian sebagian semen dengan limbah las karbit yaitu $200.47 \mathrm{~kg} / \mathrm{cm}^{2}$. Pada mortar dengan proporsi penggantian $20 \%$ semen dengan limbah las karbit didapat nilai kuat tekan mortar sebesar $157.51 \mathrm{~kg} / \mathrm{cm}^{2}$. Nilai koefisien $\mathrm{R}$ sebesar 0.95 . Pada tabel pedoman interpretasi koefisien korelasi, nilai $\mathrm{R}$ tersebut memiliki tingkat hubungan yang tinggi. Jadi, dapat dinyatakan bahwa pada saat mortar berumur 28 hari, pengaruh penggantian sebagian semen dengan limbah las karbit dengan proporsi tertentu memiliki pengaruh yang kuat terhadap nilai kuat tekan. Namun, secara grafik dapat dilihat pada Gambar 7 semakin banyaknya prosen penggantian sebagian semen dengan limbah las karbit trend nya semakin menurun. Sehingga maksimal penggantian sebesar $15 \%$ untuk memenuhi kuat tekan kelas mortar tipe M (kuat tekan minimal $175 \mathrm{~kg} / \mathrm{cm}^{2}$ ).

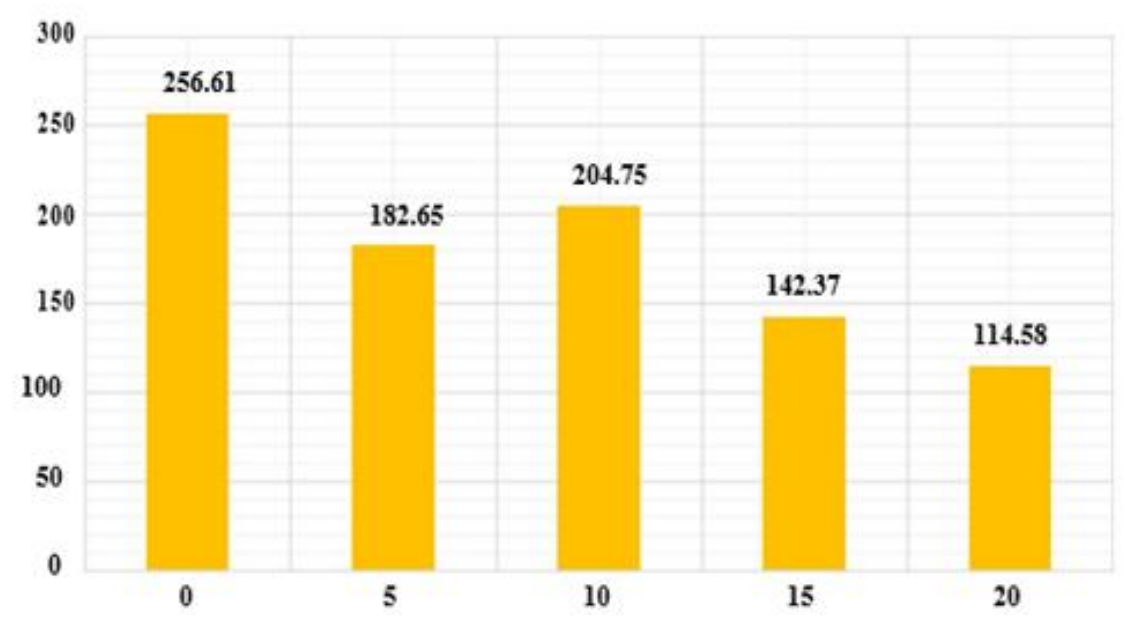

Gambar 2. Penggantian Sebagian Semen dengan Limbah Las Karbit dalam Prosen 


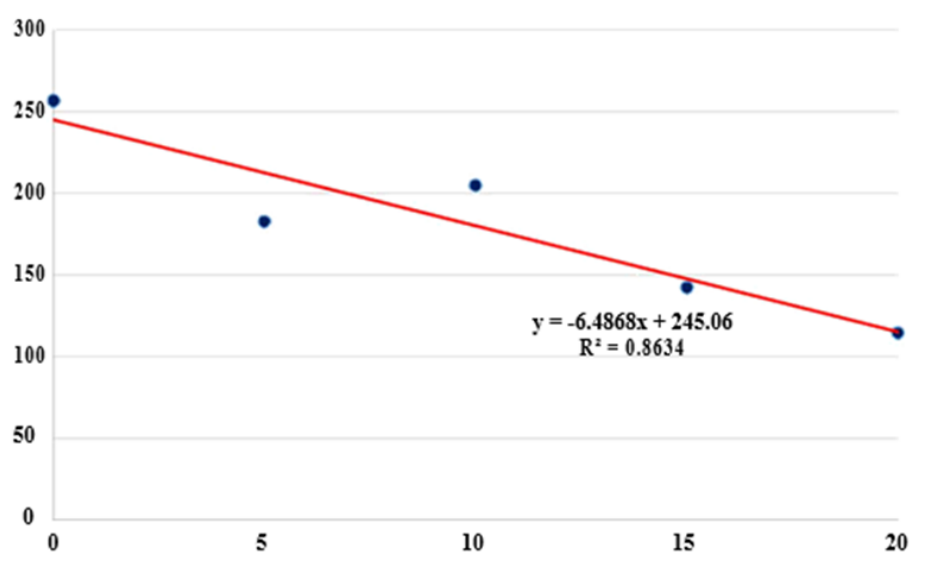

Gambar 3. Penggantian Sebagian Semen dengan Limbah Las Karbit dalam Prosen

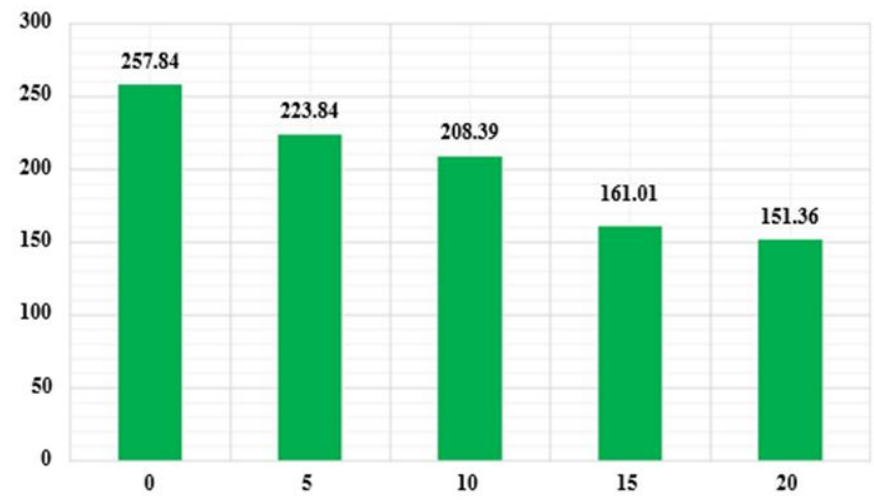

Gambar 4. Penggantian Sebagian Semen dengan Limbah Las Karbit dalam Prosen

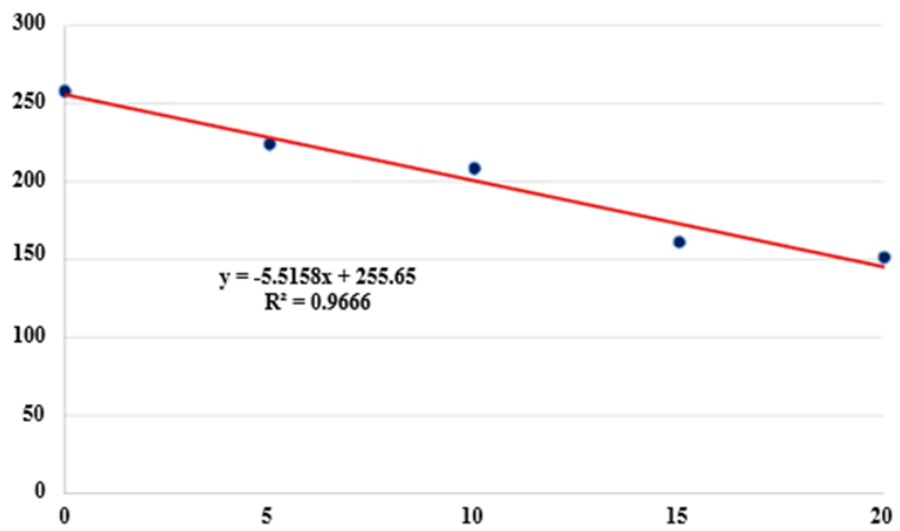

Gambar 5. Penggantian Sebagian Semen dengan Limbah Las Karbit dalam Prosen 


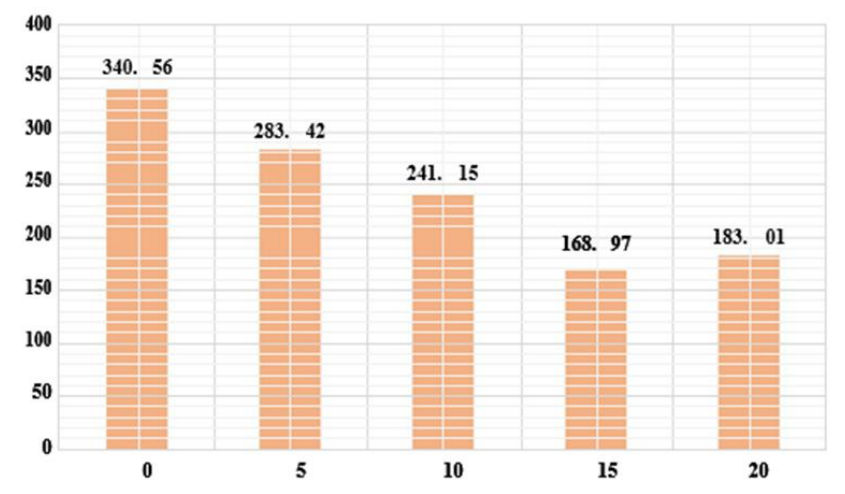

Gambar 6. Penggantian Sebagian Semen dengan Limbah Las Karbit dalam Prosen

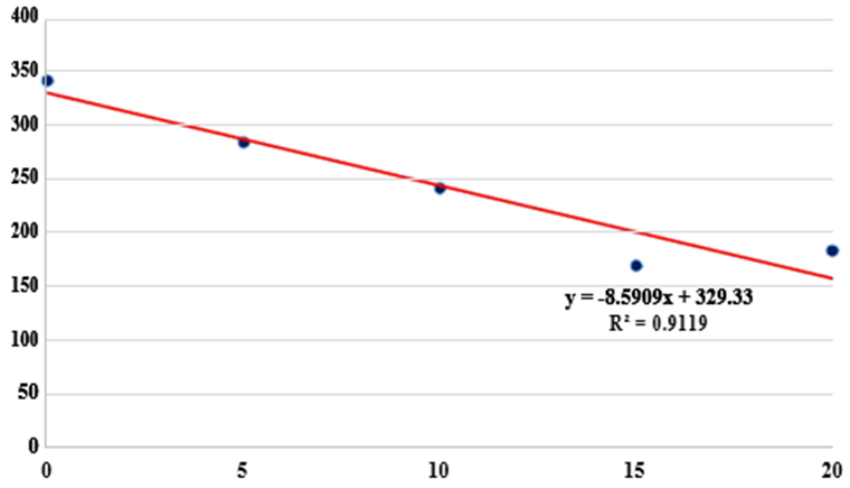

Gambar 7. Penggantian Sebagian Semen dengan Limbah Las Karbit dalam Prosen

\section{SIMPULAN}

Berdasarkan hasil dan analisa yang didapat keseluruhan mortar masuk dalam tipe mortar kelas M (SNI 036881-2002) dengan kuat tekan minimal 17.2 MPa, kecuali kuat tekan mortar dengan penggantian 20\% sebagian semen dengan limbah las karbit yaitu $157.51 \mathrm{~kg} / \mathrm{cm}^{2}$, setara dengan 15.45 $\mathrm{MPa}$. Tipe mortar kelas $M$ ini merupakan adukkan dengan kuat tekan tinggi, dapat dipakai untuk tembok bata bertulang, tembok dekat tanah atau untuk pasangan pondasi. Kuat tekan mortar dengan limbah las karbit sebagai pengganti sebagian semen tidak bisa menyamai kuat tekan mortar normal tanpa bahan tambah limbah las karbit. Kuat tekan mortar tanpa limbah las karbit yang dijadikan variabel kontrol yakni sebesar 329.33 $\mathrm{kg} / \mathrm{cm}^{2}$. Sementara kuat tekan mortar dengan proporsi penggantian sebagian semen dengan limbah las karbit 5\%, $10 \%, 15 \%$, dan $20 \%$ secara berturut turut adalah $286.38 \mathrm{~kg} / \mathrm{cm}^{2}, 243.42$ $\mathrm{kg} / \mathrm{cm}^{2}, 200.47 \mathrm{~kg} / \mathrm{cm}^{2}$, dan 157.51 $\mathrm{kg} / \mathrm{cm}^{2}$. Maksimal penggantian semen dengan limbah las karbit sebesar $15 \%$ untuk memenuhi kuat tekan kelas mortar tipe M (kuat tekan minimal $175 \mathrm{~kg} / \mathrm{cm}^{2}$ ). Hal ini terjadi karena limbah las karbit dalam pengujian ini tidak memungkinkan untuk mensubtitusi semen hingga $20 \%$ dikarenakan peran semen tidak 
tergantikan oleh limbah las karbit. Jadi, untuk mengurangi jumlah limbah las karbit dan meminimalisir penggunaan semen yang ada di lingkungan masyarakat dapat digunakan mortar proporsi penggantian $15 \%$ sebagian semen dengan limbah las karbit.

\section{DAFTAR PUSTAKA}

Ali, N., Karimah, R., \& Meiyanto, H., 2014, Pengaruh Bottom Ash Sebagai Pengganti Pasir dan Limbah Karbit Sebagai Bahan Tambah Semen Terhadap Berat Jenis, Kuat Tekan, dan Absorbsi Batako. Media Teknik Sipil, 63-70.

Aswad, N., \& Ferdyan, 2013, Penggunaan Limbah Las Karbit dan Abu Sekam Padi Sebagai Bahan Subtitusi Semen pada Paving Block. Metropilar, 244252.

Hardjito, D., Cheak, C., \& Ing, C., 2008, Strength and Setting Times of Low Calcium Fly. Modern Applied Science, 3-11.

Hartono, E., Rofi'ahza, S., \& Hemeto, A.D., 2009, Penggunaan Campuran Abu Sampah Organik dan Limbah Karbit sebagai Bahan Pengganti Semen pada Mortar. Jurnal Ilmiah Semesta Teknika, 86-91.

Latif, M.A., Naganathan, S., Razak, H.A., \& Mustapha, K.N., 2015, Evaluating The Performance of Calcium Carbide Kiln Dust in Mortar - Initial Study. ELSEVIER, 788-795.
Rahmawati, W., 2017, Volume Penjualan Semen Indonesia 26,43 Juta Ton. Dipetik Desember 29, 2017, dari Kontan.co.id:

http://investasi.kontan.co.id

Rajiman, 2015, Pengaruh Penambahan Limbah Karbit dan Material Agregat Alam (Feldspart) Terhadap Sifat Fisik Beton. TAPAK, 118-124.

Rattanashotinunt, C., Thairit, P., Tangchirapat, W., \& Jaturapitakkul, C., 2013, Use of Calcium Carbide Residue and Bagasse Ash Mixtures as A New Cementitious Material in Concrete. ELSEVIER, 106-111. Saputra, A., 2017, Pengaruh Variasi Faktor Air Semen (0,24, 0,28, 0,32) dengan Penambahan Superplasticizer $1,5 \%$ dan Limbah Las Karbit Terhadap Kuat Tekan Beton. Dipetik Desember 29, 2017, dari UMY Repository:

http://repository.umy.ac.id

SNI 03-6861.1, 2002, Bahan Bangunan Non Logam. Jakarta: Badan Standar Nasional,

Wallah, S. E., \& Pandaleke, R., 2014, Kuat Tekan Mortar Dengan Menggunakan Abu Terbang (Fly Ash) Asal Pltu Amurang Sebagai Substitusi Parsial Semen. Jurnal Sipil Statik, 252259.

Husaini, Usman, Purnomo Setiady Akbar, 2008, Pengantar Statistika. PT. Bumi Aksara. Jakarta Halaman 201-206 